\title{
Cost Benefits Analysis And Feasibility For Office Relocation In The Public Service Agency
}

\author{
Budi Wahyu Mahardhika ${ }^{1}$, Phonny Aditiawan Mulyana ${ }^{2}$, Asyidatur Rosmaniar ${ }^{3}$ \\ \{budi.wahyu.m@fe.um-surabaya.ac.id ${ }^{1}$ \} \\ Department Management University of Muhammadiyah Surabaya ${ }^{1,2,3}$
}

\begin{abstract}
The existence of a Public Service Agency in the Provision of Telecommunications and Informatics has an important role to support the availability of national communication infrastructure. To improve better performance, the agency plans to relocate its office in a $1 \mathrm{~km}$ radius from the headquarters of the Ministry of Communication and Informatics. This relocation aims to achieve ease of coordination and cooperation between the Agency and the Ministry so that in the end a significant performance improvement will be achieved. Feasibility study and Cost Benefit analysis examines how the plan will bring more benefits compared to the costs. However, relocation is not just a matter of costs and location but also to determine the extent to which predictions of employee performance improvement will be achieved from this relocation. Furthermore, improving the performance of staff is expected to bring benefits to the Indonesian people in general. Based on the results of a poll conducted on 88 staff respondents stated that the majority of respondents needed a wider living room and archive space to accommodate operational activities. Financially, the office relocation was feasible. The cost for this relocation will be the pay back period in the 5th year with an IRR of $95.74 \%$. The benefit cost ratio is 2.09 which indicates that this office relocation is feasible. Changes in conditions in which income drops $10 \%$ will cause the payback period to be reached within 5.33 years. This will also occur if there is an increase in operating costs of $10 \%$.
\end{abstract}

Keywords : cost benefits, relocation, and public service agency

\section{Introduction}

The existence of a public service agency as one of the institutions in the Information Ministry of State plays an important role to support the availability of national communication infrastructure. The various resources and facilities owned by this agency help the Indonesian government to equalize and break down telecommunications and information gaps in Indonesia. Along with this, public service agency are trying to spur better performance from year to year. For this reason, office staff who were initially active and centered at Wisma Kodel, Jalan H.R. Rasuna Said Kav B4, South Jakarta, plans to move (relocate) its office in a $1 \mathrm{~km}$ radius from the ministry office. This relocation aims to achieve ease of coordination and cooperation between public bodies and the Ministry so that in the end a significant performance improvement will be achieved.

Feasibility study and cost benefit analysis examines how the plan will bring benefits when compared to the costs. However, relocation is not just a matter of costs and location. But also to 
find out how far the predictions of employee performance improvement will be achieved from this relocation. Welfare is one's main purpose and importance in working. Similarly, the employees and management of the Public Service Agency (BLU) in Indonesia[1]. Furthermore, improving the performance of staff is expected to bring benefits to the Indonesian people in general.

There are three major factors affect estimation of the present values of the social costs and benefits of public projects that accrue over time.Those factors are (a) the relative valuation of consumption in present versus future time periods (including intergenerational time periods), (b) how to account for the opportunity cost of real resource flows over time that displace private investment as against those that displace private consumption, and (c) the appropriate treatment of risk from a social perspective.[2]

CBA (Cost Benefit Analysis) is an approach to policy recommendations that allows to compare and advocate a policy by calculating total costs in the form of money and total profits in the form of money [3]. CBA implementation in making recommendations in the public sector has characteristics that include trying to measure all costs and benefits for the community resulting from the public program. The benefit cost analysis traditionally represents economic rationality because the criteria are largely determined by the use of global economic efficiency[2]. Traditional benefit cost analysis also uses the (private) market as a starting point for recommending public policy. Contemporary cost benefit analysis, also called social benefit cost analysis, can be used to measure benefit redistribution[3]. By performing a CBA one can estimate the total surplus of benefits overcosts and thereby rank the available options before a decision is made.[4]

CBA has some advantages, first, use of economic resources efficiently. If efficiency is guaranteed, the achievement of public welfare from public policies is implemented more maximally[5], second, it is very compatible with the calculation of the benefits of policies / projects on a large or macro scale, especially those that affect the performance of regional development as a whole [6].

\section{Methodology}

In this study, the problem to be studied is in the form of open-ended questions and thus will use descriptive qualitative research method (non statistics) that is case study research. The calculation and data analysis is done by cost-benefit method. Then, calculation of sensitivity analysis done to obtain net present benefit (NPB) and IRR (PI). When the simulation results produce output where the eligibility requirements if $\mathrm{NPB}>1$, then $\mathrm{CBA}$ is feasible to do. After the analysis and calculation is done, a descriptive study was conducted on the result of the popular consultation. This is necessary because cost benefit analysis can be complicated by human factors affecting cost and benefit assessments [7]. The results of research are poured in some conclusions that answer the research question.

\subsection{Net Present Value (NPV)}

Net present value (NPV) is another common way of conducting CBA[4]. Net present value (NPV) is the net value of a project representing all the value of the project benefits deducted by the project cost in the year and calculated by the applicable discount rate. If the NPV $<0$ then the investment made can cause losses, and if NPV $=0$ then the investment made will not cause the company to be a profit or loss. The Calculations are [8]: 


$$
\begin{aligned}
& N P V=-C_{0}+\frac{C_{1}}{1+r}+\frac{C_{2}}{(1+r)^{2}}+\ldots \ldots+\frac{C_{T}}{(1+r)^{T}} \\
& \text { with: } \\
& \text { NPV }=\text { Net Present Value } \\
& \mathrm{C} 0=\text { Initial cost } \\
& \mathrm{C}=\text { Cash flow value of the year to- } \\
& \mathrm{T}=\text { Year } 0.1,2 \ldots . . . \mathrm{T} \\
& \text { Equation Err } \\
& \mathrm{r}=\text { Value discount }
\end{aligned}
$$

\subsection{Internal Rate of Return (IRR)}

IRR is an indicator of the level of efficiency of an investment. A project / investment can be carried out if the rate of return is greater than the rate of return if investing elsewhere. In this calculation method, the discount rate is sought so as to produce the present value of a project equal to zero ( Equation Error! No text of specified style in document.-2 ).

$$
\begin{aligned}
& I R R=I_{r}+\frac{N P B I_{r}}{N P B I_{r}-N P B I_{t}} *(l t-l r) \\
& \sum_{t=0}^{T} \frac{M_{t}-B_{t}}{(1+I R R)^{t}}=0
\end{aligned}
$$

Equation Error! No text of specified style in document.-2 Internal Rate of Return (IRR)

\subsection{Payback Period}

Payback Period is the time measured at the start of the investment until the achievement of a break even point condition that shows the length of time the return of costs or investments incurred in building the project. The results of the payback period calculation are expressed in units of time. Calculation of payback period is obtained by using Equation Error! No text of specified style in document.-3 :

$$
\mathrm{PP}=\frac{(\mathrm{p}-\mathrm{n})}{\mathrm{p}+\mathrm{n}_{\mathrm{y}}}=1+\mathrm{n}_{\mathrm{y}}-(\mathrm{n} / \mathrm{p})
$$

dengan :

PP = Payback Period

$\mathrm{N}_{\mathrm{y}}=$ Number of years after the initial investment where the last cash flow is negative

$\mathrm{N}=$ Value of cash flow when the last time the cash flow is minus

$\mathrm{P}=$ The value of cash flow when cash flows are first surplus 


\subsection{Cost Benefit Analysis}

The cost-benefit comparison method, also called Cost Benefit Analysis (CBA) using historical data on the number of employees, historical data on the number of guests per day, ideal employee work area, ideal living room area, meeting room area, archival space, employee salary amount and number of existing employees. The assumptions used in this cost benefit analysis study are Coordination (meeting) with a frequency of $2 \mathrm{x}$ a day with a duration of 1 hour round trip and a distance of $10.2 \mathrm{KM}$, Percentage increase in the number of employees by $110 \%$ per year, Percentage increase in the number of guests by $110 \%$ per year, Assuming a salary increase of $105 \%$ per year, the percentage of employees attending the meeting is $15 \%$ of the total number of employees, the volume of fuel used in meeting / coordination activities is 10 liters at a price of Rp. 7,350.00 / liter and Increase in building rental costs is assumed to be 5\% per year. While the operational costs that arise and are used as comparative materials, namely the difference in costs and the addition of rental space, renovation costs and furniture and household expenses, etc.

\section{Results and Discussion}

The scope of making a cost benefit analysis and feasibility study of the relocate of the Public Service Agency office are:

a. Assessing the feasibility of moving the location of office buildings in terms of the efficiency of costs and benefits that will be received by agency.

b. Feasibility analysis of the technical aspects of the condition of the building and office facilities to be used.

c. Analysis of organizational aspects includes the growth rate of employees on the availability of office space.

d. Analysis of financial aspects, including estimates of the amount of costs needed and calculation of investment feasibility (including NPV analysis, IRR, pay back period and sensitivity analysis) for the relocation of the office.

e. Analysis of employee polls about employee approval with office relocation.

The results of data collection are benefits of increasing revenue (adequate office access \& space), benefits of time travel cost savings, benefits of saving travel fuel costs and the benefits of smooth coordination with the supervisory board. So that the cash flows from the benefits obtained from the four aspects measured over 11 years are as follows in Table .

The cost for this relocation will be the pay back period in the 5th year with an IRR of $95.74 \%$. The benefit cost ratio is 2.09 which indicates that this office relocation is feasible. Changes in conditions in which income drops $10 \%$ will cause the payback period to be reached within 5.55 years. This will also occur if there is an increase in operating costs of $10 \%$.e. 
Table 1. Simulation of changing conditions when benefits fall and costs rise

\begin{tabular}{|c|c|c|c|c|c|c|}
\hline \multirow[b]{2}{*}{ No } & \multirow[b]{2}{*}{ Discussion } & \multirow[b]{2}{*}{$\begin{array}{c}\text { Normal } \\
\text { Condition }\end{array}$} & \multicolumn{4}{|c|}{ Changing Condition } \\
\hline & & & $\begin{array}{c}\mathbf{2 , 5 \%} \\
\text { *(Million Rp) }\end{array}$ & $\begin{array}{c}5 \% \\
\text { (Million Rp) }\end{array}$ & $\begin{array}{c}\mathbf{7 , 5 \%} \\
\text { (Million Rp) }\end{array}$ & $\begin{array}{c}10 \% \\
\text { (Million Rp) }\end{array}$ \\
\hline \multirow{5}{*}{1.} & Benefit Down & & & & & \\
\hline & a. Net Present Value (NPV) & 21,331 & 20,310 & 19,289 & 18,268 & 17,247 \\
\hline & b. Internal Rate of Return (IRR) & $95.74 \%$ & $90.31 \%$ & $85.11 \%$ & $80.13 \%$ & $75.35 \%$ \\
\hline & c. Cost Benefit Analysis (CBA) & 2.09 & 2.04 & 1.99 & 1.94 & 1.88 \\
\hline & d. Payback Period (PP) & 5.33 & 5.43 & 5.53 & 5.64 & 5.75 \\
\hline \multirow{5}{*}{2.} & Cost Rising & & & & & \\
\hline & a. Net Present Value (NPV) & 21,331 & 20,843 & 20,355 & 19,868 & 19,380 \\
\hline & b. Internal Rate of Return (IRR) & $95.74 \%$ & $90.44 \%$ & $85.60 \%$ & $81.16 \%$ & $77.07 \%$ \\
\hline & c. Cost Benefit Analysis (CBA) & 2.09 & 2.04 & 1.99 & 1.95 & 1.90 \\
\hline & d. Payback Period (PP) & 5.33 & 5.42 & 5.52 & 5.61 & 5.71 \\
\hline
\end{tabular}

The polls were followed by 88 respondents with the majority of the sexes of the respondents namely Men as much as $62.5 \%$ and Women as much as $37.5 \%$. From the survey results and filling out the questionnaire, information was obtained that the majority of respondents were quite satisfied with existing office facilities (54.5\%), except for living room facilities that were considered inadequate $(40.9 \%), 48.9 \%$ of respondents also argued that the archive space was inadequate .

As many as $98.9 \%$ thought that the room as a means of day care did not exist. As for the current office access from the aspect of coordination with stakeholders (including with the Ministry of Communication and Information and operators) $39.8 \%$ of respondents thought enough.Then regarding the plan to move the building / office to a maximum of $1 \mathrm{KM}$ from the Depkominfo as many as $47.7 \%$ of respondents thought agree / strongly agree.

The results of this survey obtained benefits from the transfer of offices from Wisma Kodel to Buildings near the Ministry of Communication and Information, namely (a) Benefits of increasing income (adequate access and office space facilities), (b) Benefits of saving travel time, (c) Benefits of saving fuel for round trip to work, and (d)Benefits of smooth coordination with the supervisory board.

\section{Conclusion}

Based on the results of research and discussion above, it can be concluded as follows: (a) Based on the results of the poll conducted on 88 respondents of the Public Service Agency staff stated that the majority of respondents needed a wider living room and archive room to accommodate it's operational activities, and (b) Financially the transfer of the Public Service Agency office from Wisma Kodel to a location near the Depkominfo is feasible. The cost for this relocation will be the pay back period in the 5th year with an IRR of $95.74 \%$. The benefit cost ratio is 2.09 which indicates that this office relocation is feasible. Changes in conditions in 
which income drops $10 \%$ will cause the payback period to be reached within 5.33 years. This will also occur if there is an increase in operating costs of $10 \%$.

\section{Acknowledgments.}

We would like to thank to the Dean of Economic and Bussiness Faculty and Head of Management Departement, Muhammadiyah University of Surabaya , and last but not least Ministry of Communication and Information Republic of Indonesia.

\section{References}

[1] B. W. Mahardhika, A. J. Tallo, D. E. Susilo, and W. M. Bahri, 'Analysis of Benefit Cost Car Ownership Program for Employee in the General Services Agency', J. Phys. Conf. Ser., vol. 1114, no. 1, 2018.

[2] M. A. Moore, A. E. Boardman, and A. R. Vining, 'Risk in Public Sector Project Appraisal: It Mostly Does Not Matter!', Public Work. Manag. Policy, vol. 22, no. 4, pp. 301-321, 2017.

[3] W. N. Dunn, Pengantar Analisis Kebijakan Publik (terjemahan. Yogyakarta: UGM Press, 2003.

[4] R. Lowry and M. Peterson, 'Cost-benefit analysis and non-utilitarian ethics', Polit. Philos. Econ., vol. 11, no. 3, pp. 258-279, 2012.

[5] G. Mangkoesoebroto, Ekonomi Publik. Yogyakarta: BPFE, 2001.

[6] Sjafrizal, Ekonomi Regional: Teori dan Aplikasi. Jakarta: Niaga Swadaya, 2008.

[7] H. F. Cervone, 'Using cost benefit analysis to justify digital library projects', $O C L C$ Syst. Serv. Int. Digit. Libr. Perspect., vol. 26, no. 2, pp. 76-79, 2010.

[8] M. Linn, 'Cost-benefit analysis: A primer', Bottom Line, vol. 23, no. 1, pp. 31-36, 2010. 